\title{
Occurrence of Important Viral and Bacterial Diseases in Poultry Flocks in District Khairpur Mir's, Sindh, Pakistan
}

\author{
Rehana Aslam1, Zaibun-Nisa Memon', Dilpat Rai Menghwar²*, Qalender Bux¹, Hakim Ali Keerio² \\ ${ }^{1}$ Department of Zoology, Faculty of Natural Sciences, Shah Abdul Latif University, Khairpur, Pakistan \\ ${ }^{2}$ Department of Animal Sciences, Faculty of Biological Sciences, Quaid-i-Azam University, Islamabad, Pakistan \\ Email: ${ }^{*}$ rai48_sau@yahoo.com
}

How to cite this paper: Aslam, R., Memon, Z.-N., Menghwar, D.R., Bux, Q. and Keerio, H.A. (2018) Occurrence of Important Viral and Bacterial Diseases in Poultry Flocks in District Khairpur Mir's, Sindh, Pakistan. Open Access Library Journal, 5: e4488.

https://doi.org/10.4236/oalib.1104488

Received: March 9, 2018

Accepted: April 14, 2018

Published: April 17, 2018

Copyright $\odot 2018$ by authors and Open Access Library Inc.

This work is licensed under the Creative Commons Attribution International License (CC BY 4.0).

http://creativecommons.org/licenses/by/4.0/

\begin{abstract}
The present study was conducted to determine the occurrence of two viral and one bacterial disease in four Tahsils of Khairpur District during June 2014-June 2015. The study was conduct on the clinical signs, symptoms and postmortem examination. The data were collected randomly; five farms were selected from Khairpur District. The results shows high mortality rate in all Tahsils were observed (1.17\%) due to IBD from all Tahsils followed by ND (1.13\%) as, highest number of birds affected (1.84\%) due to IBD and ND shows $(1.77 \%)$ while birds survived $(0.67 \%),(0.63 \%)$ from IBD and ND. While bacterial disease Coryza shows $(2.40 \%),(1.54 \%),(0.85 \%)$ birds affected, died and survived respectively in all Tahsils during the study period. The total number of birds affected due to IBD are 685 followed by N.D 674 and while bacterial Coryza showed 861 and total number of birds survived to IBD are 249 followed by ND 242 and while Infectious Coryza 307 from the study areas.
\end{abstract}

\section{Subject Areas}

Zoology

\section{Keywords}

Poultry, Infectious Bursal Disease, Newcastle Disease, Infectious Coryza

\section{Introduction}

Poultry can be defined as domestic fowls, including chickens, turkeys, geese and ducks, raised for the production of meat or eggs and the word is also used for the flesh of these birds used as food [1]. Poultry sector generates employment (di- 
rect/indirect) and income for about 1.5 million people. Poultry meat contributes 28.0 percent $(1,074,000$ tones) of the total meat production in the country. The current investment in Poultry Industry is more than Rs. 200.00 billion [2].

Infectious bursal disease (IBD) is a highly contagious viral disease of the growing chicken and is characterized by sudden onset, short course, and extensive destruction of lymphocytes in the bursa of fabricius, severe depression, trembling, in coordination, prostration, whitish watery or mucoid diarrhea death or recovery [3]. It is caused by a virus that is a member of the genus Avibirna and family Birnaviridae. Only young birds are clinically affected. This can cause secondary problems due to the effect of the virus on the bursa of Fabricius. It is also known as Gumboro disease, can usually be diagnosed by a combination of characteristic signs and post-mortem lesions [4]

Newcastle disease is an acute infectious viral disease of domestic poultry and other species of birds regardless of variation in sex and age [5] [6] [7]. ND causes huge economic losses to the commercial poultry farmers round the world [8] [9] [10]. Etiological agents of ND are virulent strains of avian paramyxovirus-1 [9] [11] [12]. The disease is characterized by respiratory, nervous system impairment, gastrointestinal and reproductive problems [13] [14]. Newcastle disease is commonly known as Ranikhait disease [15] [16]. Commonly affected species include chickens, turkeys, ducks, pigeons, guinea fowl, Japanese quail and many wild birds of all ages [13]. The most susceptible avian species to this disease are chickens [17]. ND is endemic and has greatest impact on villages where people's livelihood depends upon poultry farming [17] [18]. Infectious coryza is an upper respiratory tract disease of chickens caused by Haemophilus paragallinarum. Young birds grow poorly and hence, there is loss of condition in broiler, ultimately resulting in increased number of culls. Therefore, the present study was carried out to study the occurrence of important viral and bacterial diseases in poultry flocks in the district Khairpur Mirs, Sindh; Pakistan during June 2014-June 2015.

\section{Materials and Methods}

The data was record from the four cities of khairpur, Mir's, i.e. KotDiji, kumb, khura, Gambat. Five farms were selected from each study area during June 2014June 2015. During the current study a survey was conducted on commercial poultry farms. Following information was collected from the infected farms for selected viral and bacterial poultry diseases:

1) Number of Birds present at farms. 2) Number of infected Birds. 3) Number of Birds died due to diseases.

Post mortem examination were conducted both in cases of dead and affected birds to examine the gross pathological lesion in the visceral organs and other parts of the carcasses for the confirmation of selected viral and bacterial poultry diseases.

The keel bone was felt to determine if there was any pectoral muscle atrophy. 
The skin, feathers, eyes, ears and beak were examined for any disease. Took a close look at the comb and wattles any swelling or discoloration. Looked at the back of the bird for evidence of feather picking. Skin lesions were noted, they were sampled. Examined all mucous membranes (mouth, nares, conjunctiva) for any discoloration or other abnormalities. Looked at the joints for any swelling. Prior to opening the body, swabbed the trachea or cloaca. Dipped the whole carcass into a bucket of soapy water to thoroughly wet all the feathers. To expose the internal organs, the bird was laid on its back and each leg, in turn drawn outward away from the body while the skin was incised between the legand abdomen on each side.

Both legs were then grasped firmly in the area of the femur and bent forward, downward, and outward, until the heads of both femurs were broken free of the acetabular attachment so that both legs lied flat on the table. The skin was cut between the two previous incisions at a point midway between keel and vent. Removed the skin from the ventral surface of the bird by cutting across at the caudal edge of the keel and then pulled skin cranially and caudally peeled away from the muscle to expose the muscular body wall. Made a small cut into the body cavity using scissors and a scalpel blade-just behind the breast bone, then pulled the abdominal muscle caudally to expose some abdominal viscera. Extended the cut up through the cervical area and cut open the beak at the angle of the jaw. Then oral cavity, esophagus, trachea and crop were all visible. The keel bone and breast muscle was then removed by incising the pectoral muscles on each side of the keel and cutting through the ribs. Used the heavy poultry shears. Removed the keel and breast muscles entirely. The cut edge was then forcibly reflected forward, cutting was necessary, until the entire ventral aspect of the body including the neck, was exposed. Positioning shears were used to cut first the rib cage, the coracoid and clavicle on both sides with some care this was done without severing the large blood vessels. Thorough examination of the organs was done. The bursa of fabricious was located by opening the cloaca, laid on its distal side.

\section{Statistical Analysis of Data}

Data was analyzed by one-way ANOVA and by using the computer program Software Student Edition of Statistics (SXW), version 81 (copy light 2005, analytical software) USA.

\section{Results}

The results for the occurrence of important viral and bacterial diseases in poultry flocks were described (Table 1) which shows the highest numbers of bird (200) were infected from New castle disease in City Khura, while the lowest number of birds (142) were infected in Kotdiji. Higher mortality rate (134) was observed in the birds of Khura city, whereas; the lower mortality rate (90) was recorded in Kotdiji. Higher number (66) birds were survived from the infection 
Table 1. Overall percentage of affected, died and survived birds from total no: of birds examine for the viral disease of broiler in four cities of District Khairpur during 2014-2015.

\begin{tabular}{cccccccc}
\hline $\begin{array}{c}\text { Name of } \\
\text { Cities }\end{array}$ & $\begin{array}{c}\text { No: of } \\
\text { farms }\end{array}$ & \multicolumn{2}{c}{$\begin{array}{c}\text { No: of birds } \\
\text { affected \% }\end{array}$} & \multicolumn{2}{c}{$\begin{array}{c}\text { No: of birds } \\
\text { died \% }\end{array}$} & \multicolumn{2}{c}{$\begin{array}{c}\text { No: of birds } \\
\text { survived \% }\end{array}$} \\
\hline \multirow{2}{*}{ Kotdiji } & 20 & 142 & 184 & 90 & 112 & 52 & 72 \\
& & $(2.36)$ & $(1.42)$ & $(1.54)$ & $(0.86)$ & $(0.40)$ & $(0.55)$ \\
Kumb & 20 & 167 & 150 & 106 & 101 & 61 & 49 \\
& & $(1.28)$ & $(2.14)$ & $(1.81)$ & $(1.44)$ & $(0.46)$ & $(0.70)$ \\
Khura & 20 & 200 & 184 & 134 & 116 & 66 & 68 \\
& & $(2.50)$ & $(2.69)$ & $(1.67)$ & $(1.69)$ & $(0.82)$ & $(4.99)$ \\
Gambat & 20 & 165 & 167 & 102 & 147 & 63 & 60 \\
& & $(1.50)$ & $(1.61)$ & $(0.92)$ & $(1.03)$ & $(0.57)$ & $(0.58)$ \\
Total & 80 & & 685 & 432 & 436 & 242 & 249 \\
& & & $(1.84)$ & $(1.13)$ & $(1.17)$ & $(0.63)$ & $(0.67)$ \\
\hline
\end{tabular}

N.D $=$ Newcastle Disease, $\mathrm{IBD}=$ Infectious bursal disease.

of ND in city Khura and comparatively lower (52) birds could survive after the infection of ND in city kotdiji.

During present study, higher number of birds (184) were recorded for the infection of Infectious bursal disease from Kotdiji and Khura cities, lower morbidity rate (150) was observed in poultry birds of city Gambat.

Coryza was reported to infect 861 out of 35,860 birds, highest number of birds (250) from city Gambat were found to be infected with coryza (Table 2). Whereas, a lower morbidity rate (174) from city Kotdiji. Significantly higher mortality rate in birds due to the infection of coryza was observed in city Gambat followed by city Kumb (64.20\%) and city Kotdiji (62.64\%) however the lowest mortality rate (61.73\%) was recorded in city Khura. The survivability after the coryza infection was higher in city Khura $(38.26 \%)$ while lower survival rate (32\%) was observed in city Gambat.

During the present study, city wise disease occurrence was also recorded for viral disease like New castle disease (Ranikhet) and Infectious bursaldiaease (Gumboro). Table 3 and Table 4, shows the rate of occurrence for the New castle disease (Ranikhet) in four of district Khaipur during 2014-2015. Highest rate of disease appearance was recorded in city Khura where 200 birds were found to be infected from the disease followed by city Kumb (167) and kotdiji (167) respectively, while significantly $(\mathrm{p}<0.001)$ lower incidence rate was observed in city Gambat (165) during 2014-15.

During present study, higher incidence (116) birds were recorded to be infected from IBD (Gumboro) infection followed by Kotdiji (112) and Gatribat (107) cities respectively (Table 5). While, the analysis of variance shows that significantly ( $\mathrm{p}<0.001)$ lower incidence $(101)$ birds from kumb city were observed to be infected from Gumboro infection. Higher mortality percentage 
Table 2. Overall no: of birds infected, died and survived form Coryza disease in our cities of district Khairpur during 2014-2015.

\begin{tabular}{cccccc}
\hline Name of city & $\begin{array}{c}\text { No: of } \\
\text { farms }\end{array}$ & $\begin{array}{c}\text { Total no: of } \\
\text { birds }\end{array}$ & $\begin{array}{c}\text { No: of birds } \\
\text { infected }\end{array}$ & $\begin{array}{c}\text { No: of } \\
\text { birds died }\end{array}$ & $\begin{array}{c}\text { No: of birds } \\
\text { survived }\end{array}$ \\
\hline Kotdiji & 05 & 13000 & $\begin{array}{c}174 \\
(1.33)\end{array}$ & $\begin{array}{c}109 \\
(0.83)\end{array}$ & $\begin{array}{c}65 \\
\text { Kumb }\end{array}$ \\
& 05 & 5830 & 207 & 133 & 74 \\
& & & $(3.55)$ & $(2.28)$ & $(1.26)$ \\
Khura & 05 & 7310 & 230 & 142 & 88 \\
& & & $(3.14)$ & $(1.94)$ & $(1.20)$ \\
Gambat & 05 & 9720 & 250 & 170 & 80 \\
& & & $(2.57)$ & $(1.74)$ & $(0.82)$ \\
Total & \multirow{2}{*}{20} & 35860 & 861 & 554 & 307 \\
& & & $(1.28)$ & $(1.54)$ & $(0.86)$ \\
\hline
\end{tabular}

Table 3. Total number of birds affected, died and survived from Newcastle disease in four Cities of district Khairpur during 2014-15.

\begin{tabular}{cccc}
\hline Name of City & Affected & Died & Survive \\
\hline Kotdiji & 142 & 90 & 52 \\
Kumb & 167 & 106 & 61 \\
Khura & 200 & 134 & 66 \\
Gambat & 165 & 102 & 63 \\
Total & $\mathbf{6 7 4}$ & $\mathbf{4 3 2}$ & $\mathbf{2 4 2}$ \\
\hline
\end{tabular}

Table 4. Total number of birds affected, died and survived from IBD (gum boro) disease in four cities of district Khairpur 2014-15.

\begin{tabular}{cccc}
\hline Name of City & Affected & Died & Survive \\
\hline Kotdiji & 184 & 112 & 72 \\
Kumb & 150 & 101 & 49 \\
Khura & 184 & 116 & 68 \\
Gambat & 167 & 107 & 60 \\
Total & $\mathbf{6 8 5}$ & $\mathbf{4 3 6}$ & $\mathbf{2 4 9}$ \\
\hline
\end{tabular}

Table 5. Mean \pm S.E of total number of birds affected, died and survived due to N.D (Ranikhet) and IBD (Gum boro) diseases in district Khairpur during 2014-15.

\begin{tabular}{ccccccc}
\hline $\begin{array}{c}\text { Name of } \\
\text { cities }\end{array}$ & \multicolumn{2}{c}{$\begin{array}{c}\text { No: of birds affected } \\
\text { Mean } \pm \text { S.E }\end{array}$} & \multicolumn{2}{c}{$\begin{array}{c}\text { No: of birds died } \\
\text { Mean } \pm \text { S.E }\end{array}$} & \multicolumn{2}{c}{$\begin{array}{c}\text { No: of birds survived } \\
\text { Mean } \pm \text { S.E }\end{array}$} \\
\hline & ND & I.B.D & ND & I.B.D & ND & I.B.D \\
\hline Kotdiji & $11.8 \pm 3.40$ & $15.3 \pm 2.83$ & $7.50 \pm 3.03$ & $9.33 \pm 3.02$ & $4.33 \pm 1.43$ & 6.0 c \pm 2.21 \\
Kumb & $13: 9 \pm 3.4$ & $12.5 \pm 3.52$ & $8.8 \pm 4.113$ & $8.41 \pm 2.57$ & $5.08 \pm 1.88$ & $4.08 \pm 2.06$ \\
Khura & $16.6 \pm 9.4$ & $15.31=3.55$ & $11.1 \pm 7.30$ & $9.66 \pm 2.42$ & $5.50 \pm 3.14$ & $5.66 \pm 2.38$ \\
Gambat & $13.7 \pm 4.2$ & $13.9 \pm 3.05$ & $8.5013 \pm 0.57$ & $8.91 \pm 1.31$ & $5.25 \pm 2.59$ & $5.00 \pm 2.00$ \\
\hline
\end{tabular}


$(64.07 \%)$ was recorded in the poultry birds of city Gambat. Whereas: comparatively lower mortality rate (54.30\%) was recorded in the bird's f city Khura.

During present study, Mean \pm SE was also calculated to observe the statistical difference in occurrence of important viral diseases like ND (Ranikhet) and IBD (Gumboro) in four Cities of district Khairpur (Table 5). Highly significant ( $\mathrm{p}<$ 0.001 ) difference was found among the Cities for the occurrence of ND (Ranikhet); higher Mean \pm S.E $(16.6 \pm 9.4)$ were recorded for the incidence of N.D in city Khura. Whereas; lower Mean \pm S.E $(11.8 \pm 3.40)$ was recorded in city Kotdiji. Similarly higher Mean \pm S.E $(11.18 b \pm 7.30)$ for death rate of birds due to the ND infection lower Mean \pm S.E $(7.506 \pm 3.03)$ was recorded in Kotdiji city. However, the higher survival Mean \pm S.E $(5.506 \pm 3.14)$ was recorded in city Khura and lower Mean \pm S.E $(4.33 \pm 1.43)$ for the survival of birds after the important viral disease IBD (Gumboro) was also calculated as (Table 6), higher Mean \pm S.E $\left(15.3^{\prime} \pm 3.55\right)$ was recorded for the incidence of IBD in Khuracity while lower incidence Mean \pm S.E $\left(12.5^{\prime} \pm 3.52\right)$ was recorded in the birds of city Kumb. Higher mortality Mean \pm S.E $(9.66 \mathrm{~b} \pm 2.42)$ but significant $(\mathrm{p}>0.001)$ was recorded in poultry bids of city Khura. While lower Mean \pm S.E (8.41b 2.57) for the disease IBD was recorded in city Kumb birds. The survival after the infection of IBD was observed in Kotdiji city $(6.17 \pm 2.21)$ while lower survival rate $\left(4.013^{\prime} \pm 2.06\right)$ was observed in poultry birds of city Kumb.

As shown in Table 7 , the higher Mean \pm S.E $(20.8=3.35)$ for the incidence of Coryza infection was recorded in the birds of city Gainbat, while lower Mean \pm S.E $(14.5 \pm 03.68)$ was recorded for the occurrence of Coryza disease in city Kotdiji. Consequently higher Mean \pm S.E $(14.16 \pm 3.32)$ for the mortality of birds due to Coryza was observed in Gambat and lower Mean \pm S.E $(9.08=4.79)$ was

Table 6. Mean \pm S.E of birds affected, died and survived due to infectious coryza in district Kliairpur during 2014-15.

\begin{tabular}{cccc}
\hline Name of cities & $\begin{array}{c}\text { No: of birds } \\
\text { affected Mean } \pm \text { S.E }\end{array}$ & $\begin{array}{c}\text { No: of birds } \\
\text { died Mean } \pm \text { S.E }\end{array}$ & $\begin{array}{c}\text { No: of birds } \\
\text { survived Mean } \pm \text { S.E }\end{array}$ \\
\hline Kotdiji & $14.5 \pm 03.68$ & $9.08 \pm 4.79$ & $5.41 \pm 2.77$ \\
Kumb & $17.25 \pm 4.11$ & $11.08 \pm 3.89$ & $6.166 \pm 2.08$ \\
Khura & $19.16 \pm 3.01$ & $11.83 \pm 2.44$ & $7.33 \pm 2.14$ \\
Gambat & $20.8 \pm 3.35$ & $14.16 \pm 3.32$ & $6.66 \pm 2.46$ \\
\hline
\end{tabular}

Table 7. Mean \pm S.E of birds affected, died and survived due to infectious coryza in district Kliairpur during 2014-15.

\begin{tabular}{cccc}
\hline Name of City & Affected & Died & Survived \\
\hline Mean \pm S.E & Mean \pm S.E & Mean \pm S.E \\
\hline Kotdiji & $14.5 \pm 03.68$ & $9.08 \pm 4.79$ & $5.41 \pm 2.77$ \\
Khumb & $17.25 \pm 4.11$ & $11.08 \pm 3.89$ & $6.166 \pm 2.08$ \\
Kluira & $19.16 \pm 3.01$ & $11.83 \pm 2.44$ & $7.33 \pm 2.14$ \\
Gambat & $20.8 \pm 3.35$ & $14.16 \pm 3.32$ & $6.66 \pm 2.46$ \\
\hline
\end{tabular}


recorded in Kotdiji city. The survival after the infection of Coryza was found to be higher in Khura $(7.33=2.14)$ while it was significantly lower in Kotdiji $(5.41=$ 2.77).

\section{Discussion}

The overall occurrence of important viral disease in poultry flocks in district Khairpur Mir's was found to be New castle disease $7.64 \%$, infectious bursa disease $7.86 \%$ and Coryza $10.59 \%$ in 80 farms during the study. [19] reported that prevalence of Newcastle disease as $12.5 \%$. During the present study occurrence of New castle disease (64.04\%). Result of present study for the occurrence of infectious coryza is much higher than that of [20]. Infectious bursal disease (63.64\%) and infectious coryza (63.34\%) are in broiler. Highest susceptibility in birds for the occurrence of IBD (Gumboro) was seen at the age of 3 - 4 weeks in study areas. [3] [21] reported higher mortality rate (63.64\%) due to the infection of IB was recorded during present study. Our results are narratively lower than [22] reported (72.8\%) mortality in broilers of district Chakwal during 2003-4. Whereas, [23] reported $100 \%$ morbidity due to IBD affected flocks [22]. It has now become an endemic disease in poultry birds in all areas of Pakistan and causes great economic losses to the industry due to its increased mortality directly and immune-suppression indirectly. Similarly, [24] reported that highly virulent IBDV showed severe gross pathological lesions and 100\% mortality in the early passages of virus and reduction of lesions were observed in the advanced passages. IBDV actively replicate not only in target organ such as bursa of Fabricius in the infected chickens [25] but also in embryonated eggs [26].

In spite of vaccination, ND and IBD are still the most common diseases in $\mathrm{Pa}$ kistan causing great economic losses [27]. The occurrence of New castle disease (Ranikhet) was also recorded; highest mortality rate (64.09\%) was observed. Our results were 31 found to be higher than [28]. On the contrary, results (7.64\%) of overall occurrence of ND (Ranikhet) were found to be lower than [29] reported incidence rate $(9.2 \%)$. While, our findings were comparably similar but lower than [30] reported the overall incidence of ND as $7.85 \%$. Present study results were comparably lower than [31] reported. Our findings from the necropsy of dead birds for the identification of N.D (Ranikliet) was found to be similar and in close agreement with the findings reported by [31]. Newcastle disease can cause great mortality in birds without any clinical signs, sometimes reaching 100 percent in unvaccinated poultry flocks and even in vaccinated.

During present study, the prevalence of coryza was $10.59 \%$ with a significantly $(\mathrm{p}<0.001)$ higher mortality rate $(63.34 \%)$. The bacterium is normal inhabitant in the healthy birds [32]. Results of present study were further strongly supported and are in close agreement with [33]. The infection (Coryza) at times alone, as recorded in one of the outbreaks at California [34] has been incriminated to cause heavy mortality reaching up to $50 \%$ and also drops in egg production by $75 \%$ to $15 \%$ within a little span of time. 


\section{References}

[1] Anonymous (2009) Poultry the American Heritage: Dictionary of the English Language. 4th Edition, Houghton Mifflin Company.

[2] Pakistan Poultry Association. 2015-16.

[3] Lukert, P.D. and Saif, Y.M. (1997) Infectious Bursal Disease. In: Calnek, B.W., Ed., Diseases of Poultry, 10th Edition, Iowa State University Press, Ames, 721-738.

[4] OIE Terrestrial Manual, 2008.

[5] Alexander, D.J. (2003) Newcastle Disease, Other Avian Paramyxo Viruses and Pneumo Virus Infections. J. Diseases Poult, 11, 63-99.

[6] Haque, M.H., Hossain, M.T., Islam, M.T., Zinnah, M.A., Khan, M.S.R. and Islam, M.A. (2010) Isolation and Detection of Newcastle Disease Virus from Field Outbreaks in Broiler and Layer Chickens by Reverse Transcription-Polymerase Chain Reaction. Journal of Veterinary Medicine, 8, 87-92.

[7] Iram, N., Shah, M.S., Ismat, F., Habib, M., Iqbal, M., Hasnain, S.S. and Rahman, M. (2013) Heterologous Expression, Characterization and Evaluation of the Matrix Protein from Newcastle Disease Virus as a Target for Antiviral Therapies. Applied Microbiology and Biotechnology.

[8] Aldous, E.W, Mynn, J.K., Banks, J. and Alexander, D.J. (2003) A Molecular Epidemiological Study of Avian Paramyxo Virus Type-1 (Newcastle Disease Virus) Isolates by Phylogenetic Analysis of a Partial Nucleotide Sequence of the Fusion Protein Gene. Journal of Avian Pathology, 32, 239-256. https://doi.org/10.1080/030794503100009783

[9] Qin, Z.M., Tan, L.T., Xu, H.Y., Ma, B.C., Wang, Y.L., Yuan, X.Y. and Liu, W.J. (2008) Pathotypical Characterization and Molecular Epidemiology of Newcastle Disease Virus Isolates from Different Hosts in China from 1996 to 2005. Journal of Clinical Microbiology, 46, 601-611. https://doi.org/10.1128/JCM.01356-07

[10] Diel, D.J., Susta, L., Garcia, S.C., Killian, M.L., Brown, C.C., Miller, P.J. and Afonso, C.L. (2012) Complete Genome and Clinicopathological Characterization of a Virulent Newcastle Disease Virus Isolate from South America. Journal of Clinical Microbiology, 50, 378-387. https://doi.org/10.1128/JCM.06018-11

[11] Yu, L., Wang, Z., Jiang, Y., Chang, L. and Kwang, J. (2001) Characterization of Newly Emerging Newcastle Disease Virus Isolates from the People's Republic of China and Taiwan. Journal of Clinical Microbiology, 39, 3512-3519. https://doi.org/10.1128/JCM.39.10.3512-3519.2001

[12] Choi, K.S., Lee, E.K., Jeon, W.J. and Kwon, J.H. (2010) Antigenic and Immunogenic Investigation of the Virulence Motif of the Newcastle Disease Virus Fusion Protein. Journal of Veterinary Science, 11, 205-211. https://doi.org/10.4142/jvs.2010.11.3.205

[13] Nanthakumar, T., Kataria, R.S., Tiwari, A.K., Butchaiah, G. and Kataria, J.M. (2000) Pathotyping of Newcastle Disease Viruses by RT-PCR and Restriction Enzyme Analysis. Journal of Veterinary Research Communications, 24, 275-286. https://doi.org/10.1023/A:1006403017578

[14] Tiwari, A.K., Katari, R.S., Nanthakumar, T., Dash, B.B. and Desai, G. (2004) Differential Detection of Newcastle Disease Virus Strains by Degenerate Primers Based RT-PCR. Journal of the Comparative Immunology, Microbiology \& Infectious Diseases, 27, 163-169. https://doi.org/10.1016/j.cimid.2003.09.002

[15] Narayanan, M.S., Parthiban, M., Sathiya, P. and Kumanan, K. (2010) Molecular Detection of Newcastle Disease Virus Using Flinders Molecular Detection of Newcastle Disease Virus Using Flinders Tehnology Associates-PCR Tehnology Asso- 
ciates-PCR. Journal of the Veterinarski Arhiv, 80, 51-60.

[16] Ravindra, P.V, Tiwari, A.K., Sharma, B. and Chauhan, R.S. (2009) Newcastle Disease Virus as an Oncolytic Agent. Indian Journal of Medical Research, 130, 507-513.

[17] Rezaeianzadeh, G., Dadras, H., Safar, A., Ali, M. and Nazemshirazi, M.H. (2011) Serological and Molecular Study of Newcastle Disease Virus Circulating in Village Chickens of Fars Province, Iran. Journal of Veterinary Medicine and Animal Health, 3, 105-111.

[18] Mohamed, H.A., Kumar, S., Paldurai, A. and Samal, S.K. (2011) Sequence Analysis of Fusion Protein Gene of Newcastle Disease Virus Isolated from Outbreaks in Egypt during 2006. Virology Journal, 8, 1-4.

[19] Yunus, A.W., Nasir, M.K., Farooq, U. and Bohm, J. (2008) Prevalence of Poultry Diseases in District Chakwal and Their Interaction with Mycotoxicosis: 1. Affects of Age and Flock Size. The Journal of Animal and Plant Sciences, 18, 107-113.

[20] Mzuddin, M.A., Samad, S.M.L. and Kabir (2011) Mortality and Disease Status in Hyline and ISA Bown Strains of Layer Chicken Reared in Cage System in Bangladesh. Bangladesh Journal of Veterniary Medicine, 7, 9-16.

[21] Okeys, J.O.A. and Uzoulwn, M. (1985) Epidomology Infectious Bursal Disease in Broiler. Bulletin of the Veterinary Institute in Pulawy, 28-29, 73-74.

[22] Yunus, A.W., Nasir, M.K., Aziz, T. and Bohm, J. (2009) Prevalence of Poultry Diseases in District Chakwal and Their Interaction with Mycotoxicosis: 2. Effects of Season and Feed. The Journal of Animal and Plant Sciences, 19, 1-5.

[23] Islam, M.N., Rashid, S.M.H., Hoque, M.F., Juli, M.S.B. and Khatum, M. (2008) Pathologenicity of IBDV Related to Outbreaks in the Vaccinated Flocks and the Causes of Vaccination Failure. Journal of Innovation \& Development Strategy, 2, 22-30.

[24] Yamaguchi, T., kondo, T., Inoshima, Y., Ogawa, M., Miyoshi, M., Yanai, T., Masegi, T., Fukushi, H. and Hirai, K. (1996) In Vitro Attenuation of Highly Virulent Infectious Bursal Disease Virus: Some Characteristics of Attenuated Strains. Avian Diseases, 40, 501-509.

[25] Stuis, W.V. (1994) Infectious Bursal Disease Virus: Destruction of the Immune System. World Poultry, Special Supplement of Gumboro, 4-5.

[26] Hassan, M.K. and Saif, Y.M. (1996) Influence of the Host System on the Pathogenicity and Immunogenicity of Infectious Bursal Disease Virus. Avian Diseases, 40, 553-561.

[27] Numan, M., Zahoor, M.A., Khan, H.A. and Siddique, M. (2005) Serological Status of Newcastle Disease in Broilers and Layers in Faislabad and Surrounding Districts. Pakistan Veterinary Journal, 25, 55-58.

[28] Orsi, M.A., Doretto, J.R.L., Camillo, S.C.A., Reischak, D., Ribeiro, S.A.M., Ramazzoti, A., Mendonca, A.O., Spilki, F.R., Buzinaro, M.G., Ferreira, H.L. and Arns, C.W. (2010) Prevalence of Newcastle Disease Virus in Broiler Chickens (Gallus gallus) in Brazil. Brazilian Journal of Microbiology, 41, 349-357.

[29] Garba, A., Bolajoko, B.M., Barde, I.J., Ahmed, A., Adatu, I.S., Agang, I., Sabdullahi, A., Bakari, H.A., Turaki, U.A., Aabdurrahman and Goji, N.J. (2010) The Threat of Salmonellosis to Commercial Poultry Production in Adamawa State, Nigeris. Sokoto Journal of Veterninary, 8, 50-52.

[30] Abbas, G., Khan, H., Hassan, M., Mahmood, M., Naz, S. and Gilani, S.S. (2015) Incidence of Poultry Diseases in Different Seasons in Khushab District, Pakistan. Journal of Advanced Veterinary and Animal Research, 2, 141-145. https://doi.org/10.5455/javar.2015.b65 
[31] Khan, M., Arshad, Y. and Hussain, I. (2011) Epidermiology of Newcastle Disease in Rural Poultry in Faislabad, Pakistan. International Journal of Agriculture and Biology, 13, 491-497.

[32] Calnek, B.W., Barnes, H.J., Reid, C.W. and Yoder, H.W. (1991) Diseases of Poultry. 9th Edition, Wolfe Publishing Ltd., Prescott.

[33] Thitisak, W., Janiviriyasopako, R., Morris, S., Srihakim, S. and Kruedener, R.V. (1988) Causes of Death Found in an Epidermiology Study of Native Chickens in Thai Villages. Proceedings of the 5 th International Symposium on Veterinary Epidermology and Economics, Copenhagen, 25-29 July 1988, 200-202.

[34] Bland, M.P., Brickford, A.A., Charlton, B.R., Cooper, C.G. and Sommer, F. (2002) Case Report: A Severe Infectious Coryza Infectious in a Multiage Layer Complex in Central California. 51 st Western Poultry Disease Conference/32 th Convention Annual ANECA, Puerto Vallarta, 1-4 May 2002, 56-57. 